\title{
Bahasa Daerah sebagai Aset Nasional Bangsa
}

\section{Nurachman Hanafi*)}

\begin{abstract}
Abstrak
Keberadaan 270 BD di Indonesia sebenarnya sangat mengagumkan para peneliti asing karena tiap BD memiliki ciri khas pembedanya sehingga dapat dijadikan aset nasional untuk memperkaya dan mengembangkan Bahasa Indonesia (BI). Dengan menggunakan Teori Ekosistem ala Crystal (2000), akan dijelaskan bagaimana BD dapat berkontribusi dan apa kendalanya bagi pengayaan dan pengembangan BI sejalan amanat GBHN pada TAP MPR No. IV/MPR/1987.
\end{abstract}

\section{Pengantar}

Bahasa adalah sesuatu yang sangat kompleks dalam kehidupan. Tak salah jika Crystal (1987) menyatakan kekagumannya: "Mengapa bahasa menjadi objek studi yang sangat menarik? Mungkin karena keunikan perannya dalam kehidupan manusia. Ketika kita melihat sekeliling, betapa ribuan bahasa dan dialeknya mengungkapkan beragam pesona tentang dunia, sastra dan gaya hidup. Ketika melongok ke belakang, yang kita temukan sebatas gambaran dari bahasa yang mencerminkan pola pikir nenek-moyang. Menatap ke depan, kita hanya bisa merancang sesuatu yang akan datang melalui bahasa. Lantas bagaimana bahasa itu diciptakan?" (hal.1). Itulah sekilas renungan bagi setiap insan atas fenomena ciptaan Allah SWT yang satu ini yang setiap penuturnya bisa menjadi pelestari atau pembunuh potensial terhadap bahasanya (dalam Hanafi, 2005; 2008a).

Bahasa Indonesia (BI) dan Bahasa Daerah (BD) di Indonesia termasuk dalam hitungan Crystal (1987) yang kehadirannya cukup dinamis sebagai sarana komunikasi secara lintas-etnis dan intra-etnis. Demi kemaujuan dan keberlanjutan identitas nasional bangsa, BI sebagai

\footnotetext{
*) Guru Besar pada Fakultas Keguruan dan Ilmu Pendidikan Universitas Mataram
} 
bahasa modern harus terus-menerus mendapat energi leksikon ${ }^{1}$ dari beragam BD yang ada. Sekalipun Sugono (2003) berpendapat pengembangan kosakata BI berasal dari tiga sumber (BI/Melayu, BD dan Bahasa Inggris (BIng) (dalam Mahsun 2005), tetapi potensi keberlanjutan penyerapan kosakata justru terletak pada ketersediaan kosakata yang dimiliki BD yang tersebar dan membentang dari Pulau We hingga Papua dengan syarat "adanya kesederajatan kedudukan" (Mahsun 2005).

Makalah ini bertujuan mengungkapkan bahwa: (1) BD di Indonesia, yang memiliki beragam keunikan karakteristik (properti), merupakan aset nasional bangsa yang patut dilestarikan, (2) Teori Ekosistem ala Crystal (2000) dapat menjelaskan pada tataran apa BD dapat berkontribusi dalam memperkaya dan mengembangkan BI serta apa kendalanya dalam memenuhi fungsinya sejalan amanat GBHN pada TAP MPR No. IV/MPR/1987.

\section{Pembahasan}

\subsection{Sekilas Bahasa Secara Global}

Berapa jumlah bahasa yang ada di dunia hingga saat ini? Crystal (2000) mengestimasi sekitar 3000--10.000 tapi itupun masih harus dicermati lagi apakah jumlah semuanya termasuk dialek di dalamnya. Dari 10.000 bahasa, apakah semuanya dipergunakan secara produktif oleh penuturnya atau sebagian menuju kepada kematian atau kepunahan? Contohnya, di Australia semula diidentifikasi ada 270 bahasa Aborigin (BA). Dari jumlah itu ternyata 160 mengalami kepunahan, 90 menuju

\footnotetext{
${ }^{1}$ Selama ini riset tentang hubungan BI sebagai bahasa modern dengan BD hanya terikat kepada alih kosakata (lexicon transfer) baik dari BD ke BI atau sebaliknya dan belum menyentuh ranah morfo-sintaksis. Yang pertama mengacu kepada penyerapan kosakata sebagai positive interference dan yang kedua sebagai negative interference (lihat Hanafi, 2002a; 2005).
} 
kematian dan 20 masih bertahan hidup (Schmidt, 1990). Bahasa Gaelik (BG) di Sutherland Timur, Skotlandia, mengalami kepunahan (Dorian 1993). Baik Schmidt (1990) maupun Dorian (1993) menyatakan kepunahan bahasa-bahasa di belahan selatan dan barat daya dunia disebabkan oleh dominasi atau kolonialisasi Bahasa Inggris (BIng) yang terlalu kuat sehingga tidak memungkinkan bahasa-bahasa lainnya bertahan. Pola dominasi semodel ini lazim disebut konflik ala Glottophagia (Hanafi, 2002a). Sebaliknya kepunahan Kasabe dan Ubyk mendahului bahasa lainnya dari peta bumi karena mengukuti penutur terakhirnya (Crystal, 2000). Seperti lazimnya kodrat manusia, bahasa pun mengalami kelahiran (birth) dan kematian (moribund) atau kepunahan (extinction) sesuai ketentuan Sang Pencipta (Hanafi, 2005).

\subsection{Bahasa Daerah sebagai Aset Nasional}

Tidak bisa dipungkiri bahwa BD sebagai bahasa leluhur merupakan warisan yang tak ternilai harganya bagi Bangsa Indonesia sebagai penentu masa depan bangsa. Moeliono (2000) mencatat bahwa di negara kita terdapat sekitar 750 BD. Akan tetapi masih banyak BD yang belum diteliti dan terbenam di perut ibu pertiwi (Hanafi, 2002). Jika 750 BD benar adanya maka di kepulauan di luar Papua terdapat sekitar 500 BD dengan variasi dialeknya dan ragam jumlah penuturnya. Berdasarkan populasi pendukungnya, Bahasa Jawa (BJ) menempati urutan pertama dengan penutur 60 juta jiwa, Bahasa Sunda (BS) kedua dengan penutur 24 juta jiwa (Kaswanti-Purwo, 2003) sedangkan BD lainnya dalam daftar urutan. Jumlah penutur secara signifikan berkaitan dengan keberlanjutan suatu BD dengan catatan adanya pembudayaan dan pemberdayaan BD tersebut secara turun-temurun. 
Besarnya jumlah BD merupakan aset nasional bangsa yang tak terhingga jika para penuturnya menyadari betapa (dalam Hanafi, 2005):

(a) Keberagaman bahasa itu penting. Mempertahankan keberagaman bahasa erat kaitannya dengan stabilitas kesuksesan kemanusiaan. Alasannya, jika transmisi bahasa yang pluralistis melemah mengakibatkan hilangnya waris-mewariskan pengetahuan tentang kebahasaan. Melemahnya keberagaman bahasa membuat kekuatan adaptasi manusia sebagai mahluk sosial merosot sebagai akibat rendahnya pola pikir (Crystal, 2000).

(b) Bahasa pengungkap identitas sosial. Menarik apa yang diungkapkan Holmes (1860) bahwa setiap bahasa merupakan candi yang jiwa penuturnya adalah pemujanya. Bahasa bukan semata unsur dari budaya itu sendiri, juga merupakan dasar bagi semua peristiwa budaya, pengungkap identitas dan timbul masyarakatnya. Oleh karenanya, bahasa akan selalu dikenang anggota masyarakat penuturnya. Sebagai konsekuensi logis dari pengungkap identitas sosial, bahasa perlu disosialisasikan dengan argumentasi bahwa kehilangan bahasa berarti kehancuran sebuah kebudayaan.

(c) Bahasa penjejak sejarah. Van Hoorde (1998) berseloroh: "Jika Anda tidak bisa lagi berbicara bahasa ibu, itu artinya Anda telah mengucilkan diri dari sejarah silam!”. Bahasa tidak bisa dipungkiri merupakan kapsul sejarah penuturnya. Apa yang diungkapkan sebenarnya representasi dari masanya. Contoh nyata adalah tulisan teks proklamasi kemerdekaan RI yang dibacakan Bung Karno dengan ejaan lama dan pengungkapan begitu rupa merupakan cermin bahasa waktu itu yang berbeda dari teks-teks pidato kenegaraan Presiden RI berikutnya.

(d) Bahasa penyumbang pengetahuan insan. Bahasa bukan hanya medium penyampai pola-pikir manusia dalam berkomunikasi saja tapi 
bahasa juga bersistem. Di dalamnya terkandung beragam data yang dapat dikembangkan menjadi banyak cabang ilmu sesuai aspek kajian dan minat penelitinya.

(e) Bahasa itu unik dan menarik. Siapa saja boleh bangga dengan kemampuan berbahasa BIng sebagai bahasa internasional. Alasan kebanggaan itu disebabkan oleh peran BIng sebagai bahasa komunikasi budaya, bahasa sains dan teknologi, dan bahasa transaksi (trading) secara global. Kosakata (lexicon) BIng berupa peristilahan-peristilahan cukup dalam mempengaruhi bahasa-bahasa dunia.

Sebaliknya jika ditinjau dari kajian morfo-sintaksis, sesungguhnya BIng tidaklah sehebat BI maupun BD. Contoh Tabel 1 dari Hanafi (2008b) menunjukkan:

Tabel 1: Penyengat BI dan BD di Indonesia ${ }^{2}$

\begin{tabular}{|l|l|l|}
\hline Peneliti & Kelas Kata & Bahasa \\
\hline Trask (1993) & $\begin{array}{l}\text { Ajektiva } \\
\text { Adverbial }\end{array}$ & Inggris \\
\hline Hanafi (2008) & $\begin{array}{l}\text { Adjektiva } \\
\text { Adverbial }\end{array}$ & Indonesia, Sasak, Bima dan Jawa \\
& Indonesia, Sasak, Bima dan Jawa \\
& Verba & Indonesia, Sasak, Bima dan Jawa \\
& Nomina & Jawa \\
& Bilangan & Wolio \\
& Definit & Wolio \\
\hline
\end{tabular}

Tabel 1 menampilkan penyengat (intensifier) BIng hanya mampu memberi penekanan kepada ajektiva dan adverbial. Sebaliknya penyengat BI, Bahasa Sasak (BS) dan Bahasa Bima (BBm) mampu memberi penguatan kepada ajektiva, adverbial dan verba. Penyengat Bahasa Jawa (BJ) dapat memberi penekanan kepada ajektiva, adverbial,

2 Tabel 1 ini merupakan modifikasi dari Tabel 2. INTs of Languages in Indonesia (Hanafi, 2008b). 
verba dan nomina, dan penyengat Bahasa Wolio (BW) memberi penguatan pada kata bilangan dan pemarkah definit.

Contoh lainnya dapat dikemukakan berikut ini. BIng hanya bisa memberikan pemarkahan pada orang ketiga tunggal (3SG) dengan sufiks -s $($ S/he like-s Supermie $=$ dia $(\mathrm{lk} / \mathrm{pr})$ suka Supermie). Bahasa Sunda (BS) juga memiliki pemarkah orang ketiga tunggal (3SG) tapi dengan sufiks eun (Si Ani isin-eun ka kabogohna = Ani malu kepada pacarnya) (Nurjanah 2004). Selain itu, pemarkahan jamak (PL) pada nomina dan verbanya terdapat dalam BS (B-ar-udak $m$-ar-odol di buruan $=$ anakanak berak di halaman) (Hanafi, 2006). Bahasa Bima (BBm) dapat menunjukkan pemarkah keaspekan berdasarkan posisi subjek -ku (1SG.PERF) (Ra-weha-ku = Saya benar-benar telah mengambilnya) dan -na- (3SG.PERF) (Maru-na-ni = Dia benar-benar telah tidur) (Rahman dkk. 1985; Hanafi, 2008b).

Dari data BD yang telah diteliti Pusat Bahasa, sebenarnya masih banyak keunikan-keunikan properti BD yang belum dibahas lebih jauh baik pada tataran morfosintaksis maupun pragmatik. Terkadang keunikan tersebut selalu diabaikan dengan slogan "kekecualian" yang seakan tidak ada gunanya untuk diteliti lebih mendalam. Padahal, keunikan-keunikan inilah yang membuat peneliti asing kagum lalu secara diam-diam memasukkan hampir semua BD, khususnya dari Indonesia Tengah hingga Indonesia Timur, ke dalam pemetaan riset berskala internasional mereka yang berkesinambungan.

\subsection{Problema Bahasa Daerah}

Semakin pesatnya perkembangan BI modern dan ragamnya di Indonesia berimplikasi kepada eksistensi BD yang ada. Sejujurnya, 
hampir semua $\mathrm{BD}$ mengalami tekanan yang bersifat eksternal dan internal.

Tekanan secara eksternal terjadi akibat dominasi BI sebagai bahasa nasional dan kebijakan terhadap BIng sebagai bahasa primadona di sekolah-sekolah. Hanafi (2002b) mensinyalir telah terjadi kue lapis bahasa yang menempatkan posisi BD di lapisan paling bawah setelah BI di lapisan tengah dan BIng di lapisan teratas. Contoh sederhana dapat dilihat di Papua. Menurut analisis Purba (2000), pemakaian BI dalam pendidikan, pergaulan dan perdagangan di seluruh lapisan masyarakat membuat para generasi muda cenderung tidak lagi menggunakan bahasa ibunya. Dimisalkannya, Bahasa Tobati dan Kayupulau hanya berpenutur orang tua yang berusia 60 tahun dan Ormu bagi mereka yang berusia 40 tahun. Selanjutnya Purba memprediksi bahwa dalam tempo satu dekade lagi akan banyak BD di Papua bertumbangan.

Kebijakan terhadap BIng di dunia pendidikan jenjang paling bawah turut mempersempit ruang gerak BD bagi generasi termuda. Dalam Seminar TEFLIN di Bandung (8--10 Oktober 1992) telah direkomendasikan bahwa pengajaran BIng sebagai muatan lokal pada waktu itu yang bersifat opsional agar diberikan di SD mulai dari siswa kelas IV hingga kelas VI (Hanafi, 1994). Belakangan rekomendasi ini menjadi kebijakan sekolah-sekolah untuk menjadikan BIng sebagai primadonanya. Alhasil, para orangtua di perkotaan cenderung memasukkan anaknya bersekolah di sekolah-sekolah yang ada BIng-nya daripada menyekolahkan buah hatinya di sekolah biasa.

Secara internal tekanan terhadap BD disebabkan adanya kondisi yang menyulitkan mempertahankan eksistensi BD-BD tersebut. Beberapa faktor penyebab itu di antaranya: (a) adanya kompetisi antarBD di provinsi yang memiliki lebih dari satu BD mengakibatkan sulitnya 
pemilihan $\mathrm{BD}$ yang representatif sebagai muatan lokal yang harus diajarkan, (b) kurangnya tenaga peneliti bahasa menyulitkan penentuan $\mathrm{BD}$ yang baku untuk tujuan pengajaran $\mathrm{BD}$, (c) metode penelitian $\mathrm{BI}$ sering digunakan untuk meneliti BD yang sesungguhnya memiliki karakterisasi berbeda dari BI. Akibatnya, hasil penelitian tidak melahirkan teori baru, dan (d) banyak orangtua tidak mampu mewariskan BD-nya kepada anak-cucunya yang berakibat hilangnya rantai generasi penerus (Hanafi, 2002a).

\subsection{Teori Ekosistem}

Crystal (2000) mengajukan Teori Ekosistem untuk bahasa-bahasa yang nyaris punah demi pelestariannya. Konsep ini berangkat dari pandangan bahwa makhluk hidup hadir melalui jaringan yang saling berhubungan. Mengutip pendapat Mellanby (1988), ekosistem ditakrifkan sebagai sistem yang terbentuk akibat interaksi semua organisme, tumbuhan, hewan, bakteri dan lain-lain dengan faktor fisika dan kimia dari lingkungannya. Dalam konsep yang holistik, Haggett (1988) menandaskan bahwa ranah budaya maupun biologis dapat diintegrasikan ke dalam hubungan yang saling mendukung, yang dalam ekologi manusia dimaksudkan sebagai upaya menghubungkan struktur dan organisasi masyarakat kepada interaksi dalam lingkungan yang dilokalisir (dalam Hanafi, 2005). Singkatnya, sebagai suatu sistem, teori Ekosistem dalam kaitannya dengan bahasa mengedepankan perlunya (1) interaksi antarbahasa, (2) manfaat hubungan antarbahasa, dan (3) hubungan bahasa dan penuturnya. 


\subsection{Aplikasi Teori Ekosistem}

Kalau bahasa kita ibaratkan sebuah delta di satu muara maka BI adalah hasil endapan lumpur dari beragam anak sungai BD yang mengalir ke muara itu dan tertahan di sana. Endapan lumpur BD bisa kita kategorikan berdasarkan (a) asupan kosakata dan (b) asupan struktur frasa/kalimat.

Pada tataran kosakata, dapat kita cermati bahwa besarnya jumlah kosakata yang masuk ke delta BI erat kaitannya dengan besarnya jumlah penutur BD tersebut. Kenyataan ini bisa kita mengerti karena peran media cetak, elektronik, sinetron TV dan lain-lain sebagai medianya mampu memberi sumbangan kosakata BD besar terhadap pembaca dan pemirsa melalui konteks budaya yang berterima. Proses yang demikian lazim disebut positive interference yaitu interferensi yang memberi manfaat bagi BI sehingga bahasa nasional itu menjadi semakin perkasa.

Ditinjau dari teori Ekosistem, penyerapan kosakata baru BD, yang menjadi perbendaharaan kosakata BI melalui interferensi semodel ini sebagai bentuk kontribusi, menggunakan dua macam pola.

Pertama, pola langsung serap tanpa mengubah makna. Umumnya kosakata baru sebuah BD yang diserap memiliki pengertian tersendiri secara budaya menurut konsep BD itu. Contohnya, cidomo dan plecing dalam Bahasa Sasak (BSk) tidak ada padanannya dalam BD lainnya sehingga tidak bisa dipersamakan dengan delman dalam Bahasa Bali/Betawi (BB/Bw) dan urab dalam BB.

Kedua, pola langsung serap tapi mengalami perubahan makna. Misalnya, kata syirik dalam BS berarti iri atau dengki yang berbeda artinya dari syirik dalam bahasa aslinya (Arab). Kata syirik dari BS ini kemudian menjadi bagian perbendaharaan kosakata BI. 
116 Mabasan - Vol. 3 No. 1 Januari-Juni 2009: 107--119

Interferensi frasa BD terhadap frasa BI menggunakan pola langsung serap tanpa mengubah makna. Dalam konteks komunikasi verbal, sering ditemukan ucapan menurut saya dan oleh saya dengan memfokuskan pentingnya kata saya sebagai orang pertama tunggal (1SG) yang semula berasal dari BS yang diindonesiakan. Awalnya BI adalah bahasa yang lebih memfokuskan kepada peran dia sebagai orang ketiga tunggal (3SG), misalnya menurut-nya dan oleh-nya yang kata dia berganti menjadi klitik -nya. Terjadinya perluasan konsep fokus dari hanya dia (3SG) ke saya (1SG) tak terlepas karena adanya dinamika saling pengaruh dalam berbahasa berjalan secara akomodatif.

Sebaliknya teori Ekosistem menemukan kendala kontribusi BD terhadap BI pada tataran kalimat. Kendala ini disebabkan oleh adanya perbedaan: (a) tata kata (word orders) dan (b) kategori gramatikal. Keduanya melibatkan pemarkahan morfologis secara ketat.

BD yang memiliki tata kata yang sama dengan BI yaitu SVO (subjek-verba-objek), tapi tidak memiliki pemarkahan secara morfologis yang ketat, sangat mudah diserap oleh BI dengan cara mengindonesiakan unsur-unsur kalimatnya. Contohnya, bojone gendheng (BJ) menjadi isterinya sinting $(\mathrm{BI})$.

Sebaliknya, jika tata kata BD berbeda dari tata kata BI akan menyulitkan BI mengadopsinya. Artawa (1997) mengungkapkan bahwa BB memiliki tata kata ergatif OVS. Tata kata OVS tidak bisa begitu saja diadopsi BI. Dicontohkannya: Meong-e cegut kuluk arti sebenarnya adalah anjing menggigit kucing bukan kucing digigit anjing sebagai wujud terjemahan kalimat pasif yang berkorespondensi dengan kalimat aktif. Dalam Bahasa Ekagi (BE), Arthur dkk. (2001) menunjukkan bahwa tata kata Ekagi adalah SOV dengan pemarkahan morfologis yang ketat. Dia mencontohkan: Aki agio wado-tipe yang arti harfiahnya adalah 
kami barang telah mengangkat dengan sufiks -tipe sebagai pemarkah aspek PERF/PAST (telah) yang merupakan kategori gramatikal. Jelas tata kata SOV dan pemarkahan aspek yang ketat secara morfologis seperti ini tidak terdapat dalam BI. Namun demikian, ragam BD yang berbeda dari BI sesungguhnya menunjukkan kebhinekaan bentuk berpikir dari masing-masing penuturnya.

\section{Kesimpulan}

Sumbangsih BD dalam menjalankan fungsinya sebagai pemerkaya dan pengembang BI merupakan aset nasional bangsa karena adanya persamaan dan keunikan-keunikan karakterisasi masing-masing BD. Teori Ekosistem telah menunjukkan pada tataran kosakata BD bisa berkontribusi lebih luas terhadap BI jika para penuturnya memiliki kesadaran akan pentingnya BD bagi mereka. Kalaupun ada kendala pada tataran kalimat, itu semata karena begitu banyak keunikan BD yang tidak bisa diserap begitu saja oleh BI. Sekalipun demikian, kehadiran BD sebagai penyumbang sangat dibutuhkan sebagai pelestari eksistensi BI baik sekarang maupun akan datang. 


\section{Daftar Pustaka}

Artawa, Ketut. 1994. Ergativity and Balinese Syntax. Unpublished Ph.D Dissertation. Bundoora: La Trobe University.

Arthur, Simin dkk. 2001. Morfologi Bahasa Ekagi. Jakarta: Pusat Bahasa, Depdiknas.

Crystal, David. 2000. Language Death. Cambridge: CUP.

Dorian, N.C. 1993. “A Response to Ladefoged's Other View of Endangered Languages". Language 69: 575-579.

Hanafi, Nurachman. 1994. Inggronesia dan Indonggris. Makalah Seminar Hari Sumpah Pemuda di KJRI Melbourne, VIC.

-------- . 2002a. "Kolonialisasi Bahasa Inggris terhadap Bahasa Indonesia".

Jurnal Penelitian Unram. Vol. 2 No.1: 71--76.

------- .2002b. "Bahasa Daerah dan Ancaman Kepunahan". Jurnal Penelitian Unram. Vol.2 No.2: 39--45.

2005. Ancaman Kepunahan dan Pelestarian Bahasa Menurut Teori Ekosistem. Mataram: Unram (Pidato Pengukuhan Guru Besar).

2006. Morphology. Mataram: Mataram University Press.

. 2008a. "Teori Al Qur'an tentang Bahasa". Lisdaya, Edisi I Th IV: $1--7$.

------ . 2008b. "Intensifier of Languages in Indonesia: A CrossLinguistic Study". Edu-Lingua Vol 1 No.2: 99--111.

Kaswanti-Purwo, Bambang. 2003. Penelitian Bahasa Nusantara di Indonesia. Makalah Seminar Hari Bahasa-Ibu Internasional di Jakarta 19-02-2003. 
Mahsun. 2005. Dinamika Bahasa Indonesia dalam Kebinekaan Bahasa Daerah. Makalah Seminar Bahasa dan Sastra di Mataram 7--8 Maret 2005.

Moeliono, Anton. 2000. "Kedudukan dan Fungsi Bahasa Indonesia dalam Era Globalisasi". Dalam Alwi dkk (eds.). Bahasa Indonesia dalam Era Globalisasi. Jakarta: Pusat Pembinaan \& Pengembangan Bahasa, Depdiknas.

Nurjanah, Enung. 2004. The Syntax of - eun in Sundanese. Unpublished S.Pd. thesis. Mataram: FKIP Unram.

Purba, Theodorus T. 2000. "Variasi Struktur Bahasa Darah Irian Jaya". Linguistik Indonesia. No.1 Th 18: 77--79.

Rachman, A dkk. 1985. Sistem Morfologi Kata Kerja Bahasa Bima. Jakarta: Pusat Pembinaan \& Pengembangan Bahasa, Depdikbud.

Schmidt, Anette. 1990. The Loss of Australia's Aboriginal Language Heritage. Canberra: Aboriginal Studies Press. 